\title{
A Study on Relationship between Qualities of Work Life on Organizational Commitment among Health Care Professionals
}

\author{
Dr.A.Diraviam \\ Assistant Professor, Department of Business administration, Bharathidasan University constituent college, \\ Nannilam, Tamil Nadu
}

\begin{abstract}
The present study aimed to evaluate the relationship between dimensions of quality of work life and organizational commitment dimensions of Health care professionals in Thanjavur district. The study is descriptive-correlation. Among 304 Health care professionals in Thanjavur district., 170 Health care professionals were selected by random cluster sampling method. For data collection, questionnaires of quality of work life of Walton (1973) and organizational commitment survey of Allen and Meyer (1990) were applied. The data were analyzed by descriptive, inferential indices including Pearson correlation test, path analysis and regression. The results showed that quality of work life had significant association with organizational commitment. Among dimensions of quality of work life, Safe and healthy working, Opportunity for continued growth and security, Constitutionalism in the work organization, Work life social dependence, Social integration in the work and immediate opportunity to develop Human progress capabilities had significant relation with three dimensions of organizational commitment (normative, continuance and affective commitments) and Adequate and fair compensation dimensions and total life space had significant relation with affective and normative commitment dimensions. Also, quality of work life could predict a part of organizational commitment score. The special attention to life quality of employees form managers of organizations can make the employees attached and loyal to organization.
\end{abstract}

Keywords: Quality of work life, Organizational commitment, Health care professionals.

\section{Introduction}

Today, considering human resources has taken much attention in organizations. Training and improving the quality of work life, abilities and skills, motivation and work creativity, CRM, job satisfaction, promotion and rewarding methods and the like are turned into important issues (Yavari, Amirtash and Tondnevis, 2009). Quality of work life is one of the most important issues in management of human resources in organizations requiring specific attention. This concept includes all work issues of employees as conditions of work place, management conditions and services compensation, etc. in the past two decades (Shermerhon et al., 2000).

The quality of work life is important for the organization performance and it is an effective factor to increase the motivation of employees at work place (Gupta \& Sharma, 2011). The concept of quality of work life emphasizes on real respect to people at work place (Rezayian, 1999:20). Thus, in value system of quality of work life, investment on people is one of the most important variables in strategic management. It means that fulfillment of the needs of employee leads to long-term improvement and efficiency of organization (Richard b, 2007). Indeed, quality of work life indicates a type of organizational culture or management method by which the employees feel ownership, autonomy, responsibility and self-esteem (Dolan and Shuler, Translated by Tusi and Saebi, 2005:354) and effectiveness and efficiency of organization is increased via increasing esteem, position and promotion of people (Mosadeghrad and Seifi, 2005). Indeed, vitalization of Employees via improving quality of work life is a key success of each organization (Bazaz Jazayeri and Pardakhtchi, 2007). Quality of work life is one of the organization development techniques attempting to provide three factors of motivation, satisfaction, responsibility and commitment to work together (Greenberg \& Baron, 1997).

It is possible that one person has thousands of attitudes but in organizational behavior issue, only some of the attitudes relevant to job of people are considered.One's attitude to his work indicates negative or positive assessment regarding work place aspects. Most of the studies on behavior field are based on three job attitudes of people in relevant work organizations. These three attitudes include job satisfaction, job dependency and organizational commitment (Robbins, Translated by Parsayian and Mohammadi, 2007:282). Among these attitudes, organizational commitment in the past decade has dedicated important position in organizational behavior researchers (Mansuri et al., 2009). Commitment is an important and basic construct in psychology and means insistence on an act or work (Cohen, 2003). Psychologists have mostly focused many years on commitment element in various fields. Commitment at work place is an important issue. As great part of people life is dedicate to organizations and work, the research on different commitments at work place is important to understand the behavior of people at work place. Indeed, the psychologists have mostly focused on the study of commitment at work place (Morrow, 1993). Organizational commitment is defined by various forms but all these 
definitions emphasize on unity of people with organization (Spector, 2007). The concept of organizational commitment is based on Mowda et al., (1979) studies and it is defined as one's attachment to organization.

These researchers believe that a person with high organizational commitment is inclined to stay in organization and work with more efforts for organization and accept the values and goals of organization. According to Perry (1991), if the organization achieves its goals with clear mission, good strategies, efficient organizational structures and good job design, it requires empowered and committed human resources (Rezayian, 1999, 391).

The managers of the organizations increasing productivity, to improve attitudes, increasing motivation of people for better work and increasing commitment to organization attempt to reduce leave, job absence and other behaviors and they also attempt to increase organization productivity and job performance of employees (Saatchi, 2007).

The organization considering the quality of life of employees has committed labor force and high commitment of labor force means high productivity of labor force (Organ, 1988). Lees \& Sandra (2005), Considine \& Callus (2003) in the studies showed that improvement of quality of work life was effective explicitly and implicitly on increasing total satisfaction of employees, belonging, positive self-concept and with others, coping up and improvement of performance of organization. Thus, beside quality of work life, organizational commitment is raised and both are the most important motivational issues in industrial and organizational psychological studies. Regarding the researches on organizational commitment, for various reasons and difficulty of definition and measurement of organizational commitment, interaction of various variables at micro and macro levels, objective and subjective levels, difference of cultures and theories in explanation of organizational commitment, we cannot generalized the results of these studies with assurance to similar cases. It is worth to mention that as organizational commitment is an internal motivation, its estimation is not easy for authorities and such evaluations can be performed in scientific researches and standard tools and their results can be given to managers and authorities of organizations (Sharifi, Salimi, Ahmadi, 2010). Identification of factors relate to quality of work life is of great importance ( Tavakoli, Legzian, Davoudnia, Alizade Zavarem, 2013). By making change in each of the factors, we can affect quality of work life. Based on the effective experience of quality of work life in financial and economic institutions and importance of commitment of employees, this study evaluates the relationship between dimensions of quality of work life with dimensions of organizational commitment among the health care professionals in a different organization and geography (Education department of Neyriz town).

Lees \& Sandra (2005:3) considered improvement of quality of work life as necessary for organizations. The indices of quality of work life for them are committed to organization, support of management of employees, support of co-workers, trust climate, leadership perception, mutual respect, self-expression and identification, non-materialistic reward, materialistic reward and communication of the same level people.

This study applied Walton (1973) theory regarding quality of work life and organizational commitment survey of Allen and Meyer (1990). An explanation of this survey is explained as followings:

Walton (1973) in his theory as one of the comprehensive theories of quality of work life considers 8 main dimensions as the increase goal (QWL) as:

1. Adequate and fair compensation, it is regarding the wage given to the organization employees and internal organizational equality is extracted from it.

2. Safe and healthy working, the aim of this item is establishing reasonable working hours and work physical conditions with the least risk and creating age limitations for employment are considered.

3. Human progress capabilities, the aim of this variable is to provide some opportunities as autonomy, selfcontrol, using various skills, access to the information of planning future and activities execution for employees.

4. Opportunity for continued growth and security, this is provided via improvement of individual abilities, progress opportunities, income safety and employment.

5. Social integration in the work, lack of bias to race, gender and labor force, moving to the top of organizational hierarchy, creating sociability feeling in organizations, freedom of speech are the examples useful in organizational integration creation.

6. Constitutionalism in the work organization, this variable is considered in the form of freedom of speech (disagreement to supervision attitudes in organization without any fear from him) to (reaction right to all issues as wage, reward and job security) and influence of law dominance compared to human dominance.

7. Total life space, creating direct dependency to work to total life space is created via establishing balance between the worker time at work place and his time for the family and this can lead to balance between work and life.

8. Work life social dependence, different discussions are presented in this regard. It means that useful social roles of organization and the effects of social problems and its activities are the problems of employees. It canbe said that the organizations not feeling their social responsibility show disrespect to value of work and 
the job of their employees as a basis to fulfill the self-esteem requirements (Morhed and Griffin, 1995).

Allen and Meyer published more than 15 researches regarding organizational commitment since 1984 and had the major role in this regard. Allen and Meyer (1990) define organizational commitment as intention of employees to stay in organization (Allen and Meyer, 1990). According to Allen and Meyer, organizational commitment dimensions include:

1. Affective commitment: It refers to emotional link of employee, identity and participation in affairs of organization. The employees with strong affective commitment continue their work in organization as they try to work (Rego, 2008:60).

2. Continuance commitment: It refers to awareness of cost of leaving organization. The employees with main link of organization due to continuance commitment stay in organization as they need this work (Rego, 2008:60). Most people are obliged to continue work as they don't want to lose it as there is no alternative. These people have high degree of work continuance commitment. Today, the increase of tendency to leave reflects low importance of continuance commitment (Greenberg, J., \& Baron, 2000:183).

3. Normative commitment: It is less common but commitment is a set of internalized normative pressures for activities (Ashrafi Soltani Ahmadi et al., 2010). Indeed, normative commitment reflects obligation to continue work. The employees with high level of normative commitment feel that they should stay in organization (Rego, 2008:60).

Quality of work life is one of the most important issues affecting employees and organization and many researchers have been regarding its relation with other organizational variables (Dolan et al., 2007). Most of the studies dealing with the relationship between quality of work life and organizational commitment have achieved some results regarding significant association between them as the study of Michelle Fields and James Tucker (1992) as "the effect of quality of work life on organizational commitment" and evaluated the changes in organizational commitment after performing quality of work life program in US. They found that after performing quality of work life plan, loyalty of members to union and their responsibility can be increased significantly. Farid, Izadi, Arif Ismail, I., \& Alipour (2015) in the study "Relationship between quality of work life and organizational commitment among lecturers in a Malaysian public research university of Klang Valley investigated 2902 lecturers based on formal website of University. The results of correlation and linear regression showed that there was a significant relationship between quality of work life and organizational commitment. This study based on existing review of literature showed that some of strategies of human resources development regarding the management of University can improve the commitment and efforts of employees.

Mahdad, Mahdavirad and Golparvar (2011) in a study evaluated the relationship between dimensions of quality of work life with organizational commitment and its components. The study data were analyzed by Pearson correlation coefficient and stepwise regression. The results of analysis showed that there was a significant relation between Adequate and fair compensation, Opportunity for continued growth and security, Human progress capabilities, with three organizational dimensions of affective, continuance and normative. Also, there was a significant relation between Safe and healthy working with affective and normative commitment, between Constitutionalism in the work organization and Social integration in the work with continuance and normative commitment. The study showed that there was a significant relation between dimensions of quality of work life, organizational commitment and its components and quality of work life dimensions were predictor of organizational commitment and its components. In another study Keshavarz, Khademi, Shamain, Razavi and Abaspour (2013) evaluated the relationship been quality of work life and organizational commitment of staff employees of Medical Sciences University of Torbat Heidarie. The results showed that there was a positive and significant relation between quality of work life and organizational commitment of staff employees of Medical Sciences University (0.56). Also, the quality of work life and organizational commitment of employees was significantly higher than mean and it was satisfactory. The results of regression analysis showed that among components of quality of work life, Adequate and fair compensation had the highest prediction capability of organizational commitment of staff employees of Medical Sciences University. Also, Niknam (2014) in a study determined the relationship between quality of work life and organizational commitment of employees of Bank Maskan of Tehran city. The Pearson correlation coefficient (0.667) showed that there was a positive and direct association between quality of work life and organizational commitment of employees of Bank Maskan of Tehran city. Also, the relationship between quality of work life and organizational commitment dimensions was direct and significant. Based on the over mentioned items, we can say various factors affect people and their performance in organization. Education system consists of various elements and each of the elements is effective on promoting the goals. Teacher as one of the elements has special role in education system and considering the effective factors on teacher, their attitude and motivation as quality of work life, job satisfaction, organizational commitment, organizational justice, organizational trust, etc. can 
help the authorities of education system in promotion of quality of work and teacher view to organization and his work. Based on the importance of mentioned items, the study aimed to evaluate the relationship between quality of work life and organizational commitment in primaryhealth care professionalsof Thanjavur district. to give information to the relevant authorities about taking strategic plans and decisions to improve performance of health care professionals.

The following hypotheses are tested:

1. There is a relationship between quality of work life and organizational commitment.

2. There is an association between dimensions of quality of work life (Adequate and fair compensation, Safe and healthy working, Opportunity for continued growth and security, Constitutionalism in the work organization, Work life social dependence, Total life space, Social integration in the work and Human progress capabilities) and organizational commitment dimensions (affective, continuance and normative commitments).

3. Quality of work life predicts organizational commitment.

\section{Methodology}

commitment (8 items) and normative commitment (8 items) scoring strongly disagree (1) to strongly agree (5). This scale was translated into Persian by Shekarkan (1996) in Iran (Pasha and Khodadadi Andrie, 1999). The scoring of this questionnaire is as the responses had strongly agree (5), agree (4), No idea (3), disagree (2) and strongly disagree (1). In this questionnaire, the questions 2, 3, 6, 10, 11, 17, 20 are scored inversely. The maximum score of a person is 120 and minimum score 24 . The reliability coefficient of this questionnaire is 0.91 by Mahdad, Mahdavirad and Golparvard, 2011, 0.75 by Sharifi et al., (2010) and Ferdousi, Marashian and Talebpour (2012) achieved reliability coefficient of this questionnaire by Cronbach's alpha 0.87 and split half method 0.83. Cronbach's alpha value for organizational commitment questionnaire is 0.76 . For data analysis, descriptive indices (mean, standard deviation of age and teaching experience variables) and inferential statistics (Pearson correlation, regression and path analysis) are used.

\section{Study Findings}

This study is applied in terms of purpose and descriptive-correlation in terms of data collection. The study population is all Health care professionals of Thanjavur district. 170 Health care professionals are selected by clustering random method.

Three following measures are used for data collection.

1- Questionnaire of quality of work life:

This questionnaire is designed by Walton (1973) in 32 items in 8 dimensions (Adequate and fair compensation, Safe and healthy working, Opportunity for continued growth and security, Constitutionalism in the work organization, Work life social dependence, Total life space, Social integration in the work and Human progress capabilities). Likert scale was used ranging from very low (1) to very much (5). The scoring of this questionnaire is as very much (5), much (4), average (3), low (2) and very low (1). In this questionnaire, questions 21, 22, 23 are scored inversely. The maximum score of a person is 160 and minimum score 32. The reliability coefficient of questionnaire is 0.92 by Maleki Avarsin: Khadivi and Khanashkizade (2012) after performing on a 30 people sample via Cronbach's alpha. The Cronbach's alpha for the questionnaire of quality of work life is 0.93 .

\section{2- Questionnaire of organizational Commitment:}

This questionnaire was designed by Allen and Meyer (1990) based on 24 items in three dimensions of affective ( 8 items), continuance Table 1 shows the mean, standard deviation, minimum and maximum score in age and teaching experience.

Table 1. The mean and standard deviation of age and teaching experience $(n=170)$.

\begin{tabular}{|l|l|l|l|l|l|}
\hline Max & Min & SD & Mean & Variable & \\
\hline 55 & 24 & 8.31 & 40.34 & Age & \\
\hline 31 & 1 & 8.62 & 18.02 & Teaching & \\
\cline { 6 - 7 } & & & & & \\
\hline & & & & & \\
\hline
\end{tabular}

As shown, the minimum age of sample is 24 years, maximum age of sample is 55 years and the mean of age of sample members is 40.34. As shown in the Table, the minimum teaching experience of sample is 1 year, maximum teaching experience 31 years and the mean teaching experience of sample is 18.02. 
Table 2 shows descriptive indices of quality of work life and its dimensions regarding the sample study.

Table 2. The mean and standard deviation of quality of work life $(n=170)$.

\begin{tabular}{|c|c|c|c|c|}
\hline Max & Min & SD & Mean & Variable \\
\hline \multirow[t]{2}{*}{21} & \multirow[t]{2}{*}{5} & \multirow[t]{2}{*}{3.04} & \multirow[t]{2}{*}{9.92} & Adequate and fair \\
\hline & & & & compensation \\
\hline \multirow[t]{4}{*}{15} & \multirow[t]{2}{*}{3} & \multirow[t]{2}{*}{2.80} & \multirow[t]{2}{*}{9.01} & Safe and healthy \\
\hline & & & & \multirow[t]{2}{*}{ working } \\
\hline & & & & \\
\hline & & & & Opportunity for \\
\hline \multirow[t]{3}{*}{15} & 3 & 2.84 & 9.78 & continued growth \\
\hline & & & & and security \\
\hline & & & & Constitutionalism \\
\hline \multirow[t]{2}{*}{30} & 6 & 5.25 & 17.93 & in the work \\
\hline & & & & organization \\
\hline \multirow[t]{2}{*}{15} & \multirow[t]{2}{*}{3} & \multirow[t]{2}{*}{2.74} & \multirow[t]{2}{*}{9.37} & Work life social \\
\hline & & & & \multirow[t]{2}{*}{ dependence } \\
\hline 25 & 5 & 3.57 & 15.17 & \\
\hline \multirow[t]{4}{*}{20} & \multirow[t]{2}{*}{4} & \multirow[t]{2}{*}{3.35} & \multirow[t]{2}{*}{13.75} & Social integration \\
\hline & & & & in the work \\
\hline & & & & Immediate \\
\hline & & & & opportunity to \\
\hline \multirow[t]{3}{*}{15} & 3 & 2.39 & 8.42 & develop Human \\
\hline & & & & progress \\
\hline & & & & capabilities \\
\hline 151 & 32 & 19.50 & 93.33 & Total score \\
\hline
\end{tabular}

As shown, the mean of scores of quality of work life is (93.33). Thus, the sample is in relatively good level in terms of condition of work life quality. Among dimensions of quality of work life, the sample members in social integration in work had good condition compared to other dimensions. Among quality of work life dimensions, Adequate and fair compensation had not good condition compared to other dimensions. The mean of Adequate and fair compensation is 9.2, Safe and healthy working 9.01, Opportunity for continued growth and security 9.78, Constitutionalism in the work organization 17.93, Work life social dependence 9.37, Total life space 15.17, Social integration in work 13.75 and immediate developed for Human progress capabilities 8.42. The minimum score of sample from quality of work life was 32 and maximum score 151 .

Table 3 shows descriptive indices of organizational commitment and its dimensions regarding the sample study.

Table 3. The mean and standard deviation of organizational commitment $(n=170)$.

\begin{tabular}{|l|l|l|l|l|}
\hline Max & Min & SD & Mean & Variable \\
\hline & & & & \\
\hline 40 & 14 & 5.42 & 31.87 & Affective \\
\hline & & & & \\
\hline 36 & 18 & 3.33 & 26.05 & Continuance \\
\hline & & & & \\
\hline 38 & 16 & 4.08 & 28.80 & Normative \\
\hline & & & & \\
\hline $\mathbf{1 1 4}$ & $\mathbf{5 7}$ & $\mathbf{1 0 . 7}$ & $\mathbf{8 6 . 7 2}$ & Total score \\
\hline & & & & \\
\hline
\end{tabular}

As shown, the mean of organizational commitment scores is 86.72 . The mean of subscale of affective commitment is 31.87 , continuance commitment 26.05 and normative commitment 28.80 . Thus, the required sample is at good level in terms of organizational commitment. Among organizational commitment dimensions, the study sample in affective dimension has good condition compared to other dimensions. The minimum score of study sample of organizational commitment variable is 57 and maximum score 114 .

The first hypothesis of study is regarding the relationship between quality of work life and organizational commitment. To investigate this hypothesis, Pearson correlation test is used. Table 4 shows the correlation results. 
Table 4. The correlation of quality of work life and organizational commitment.

\begin{tabular}{|l|l|l|l|}
\hline $\begin{array}{l}\text { Significance } \\
\text { level }\end{array}$ & $\begin{array}{l}\text { Correlation } \\
\text { value }\end{array}$ & $\mathbf{N}$ & Variable \\
\hline & & & Quality of \\
\hline 0.001 & 0.54 & 170 & work life \\
\cline { 4 - 4 } & & & Organizational \\
\hline & & commitment \\
\hline
\end{tabular}

As shown in the above Table, correlation coefficient value between quality of work of life and organizational commitment is 0.54 and as $(\mathrm{P}<0.01)$, there is a direct and significant relationship between quality of work life and organizational commitment of health care professionals. First hypothesis of study is supported.

Pearson correlation coefficient between quality of work life dimensions and organizational commitment dimensions and significance of coefficients are shown in Table 5.

Table 5. Correlation of quality of work life dimensions and organizational commitment dimensions.

\begin{tabular}{|c|c|c|c|c|}
\hline $\begin{array}{l}\text { Manmative } \\
\text { com-mitiment }\end{array}$ & $\begin{array}{l}\text { Continuanes } \\
\text { contritument }\end{array}$ & $\begin{array}{l}\text { Affective } \\
\text { commingur }\end{array}$ & & \\
\hline a.2.2- & 0.12 & $023 \div$ & 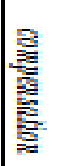 & 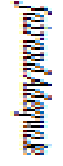 \\
\hline $0.43=-$ & $038 \div$ & $039 \div$ & 로를 & 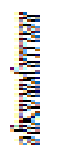 \\
\hline 10.4E- & $023 \div$ & $0.53 *$ & 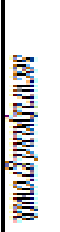 & 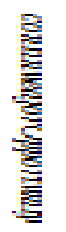 \\
\hline 口.3.5 $=$ & $029+4$ & $048++$ & 㖕 & 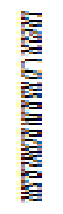 \\
\hline 10.3as- & $0.29 \div+$ & $0.42 \div+$ & 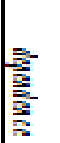 & 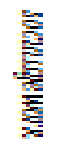 \\
\hline
\end{tabular}

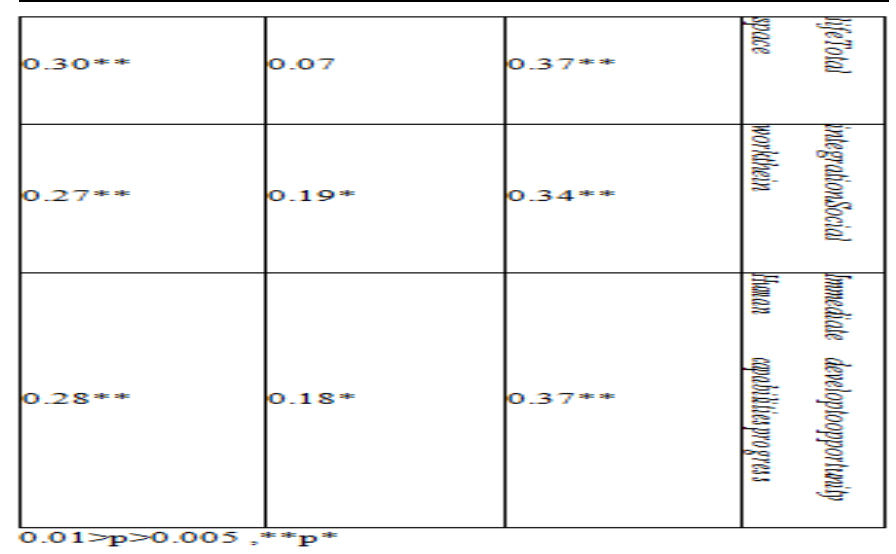


As shown in the above Table, correlation coefficient of Adequate and fair compensation with affective and normative commitment at significance level $(0.01)$ is $0.23,0.22$, respectively. Thus, there is a positive and significant relationship between Adequate and fair compensation with dimensions of affective and normative commitment. There is no significant association between with continuance commitment.

As shown in the above Table, correlation coefficient of Safe and healthy working with dimensions of affective, continuance and normative commitments at significance level $(0.01)$ is $0.39,0.38,0.43$, respectively. Thus, there is a positive and significant relationship between Safe and healthy working with dimensions of affective, continuance and normative commitments.

As shown in the above Table, correlation coefficient of Opportunity for continued growth and security with dimensions of affective, continuance and normative commitments at significance level $(0.01)$ is $0.53,0.23$, 0.46 , respectively .Thus, there is a positive and significant relationship between Opportunity for continued growth and security with dimensions of affective, continuance and normative commitments .

As shown in the Table 5, correlation coefficient of Constitutionalism in the work organization with dimensions of affective, continuance and normative commitments at significance level $(0.01)$ is $0.48,0.29$, and 0.38, respectively. Thus, there is a positive and significant relationship between Constitutionalism in the work organization with dimensions of affective, continuance and normative commitments.

As shown in the Table 5, correlation coefficient of Work life social dependence organization with dimensions of affective, continuance and normative commitments at significance level $(0.01)$ is $0.42,0.29$, and 0.38 , respectively. Thus, there is a positive and significant relationship between Work life social dependence with dimensions of affective, continuance and normative commitments.

As shown in the Table 5, correlation coefficient of Total life space organization with dimensions of affective and normative commitment at significance level $(0.01)$ is $0.37,0.30$, respectively .Thus, Total life space has direct and positive relation with affective and normative commitment but it has no significant relation with continuance commitment.

As shown in the Table 5, correlation coefficient of Social integration in the work with dimensions of affective, continuance and normative commitments at significance level $(0.01)$ is $0.34,0.19$, and 0.27 , respectively. Thus, there is a positive and significant relationship between Social integration in the work with dimensions of between Social integration in the work and affective, continuance and normative commitments.

As shown in the Table 5, correlation coefficient of immediate human progress capabilities with dimensions of affective, continuance and normative commitments at significance level $(0.01)$ is $0.37,0.18$, and 0.28 , respectively. Thus, there is a positive and significant relationship between immediate human progress capabilities with dimensions of affective, continuance and normative commitments.

Based on Table 5, among quality of work life dimensions, the highest correlation coefficient with continuance commitment $(0.38)$ at significance level $(0.01)$ is Safe and healthy working, highest correlation coefficient with affective commitment (0.53)an normative (0.46) at significance level (0.01) with growth opportunity.

The evidences of Table 5 show the relationship between dimensions of quality of work life with organizational commitment dimensions. Thus, second hypothesis of study is supported.

To investigate the predicting role quality of work life in organizational commitment, path analysis in AMOS software is used. Table 6 shows the regression results of conceptual model lines of study.

Table 6. Prediction of organizational commitment by quality of work life.

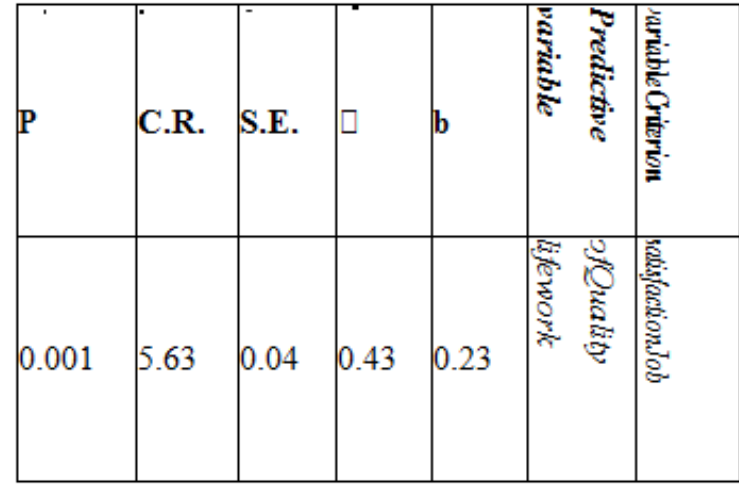

As shown in Table 6, quality of work life is a positive predictor of organizational commitment. Based on the above Table, the direct effect of quality of work life on organizational commitment is 0.43 . Thus, third hypothesis is supported. 


\section{Discussion And Conclusion}

To test the above hypotheses, statistical methods of Pearson correlation coefficient and path analysis and regression are used. Based on the results of study, correlation coefficient is significant. In other words, there is a direct and significant relation between quality of work life and organizational commitment and its dimensions. The regression results between quality of work life and organizational commitment show the significant effect of quality of work life in regression. The effect of regression in relevant significance level is significant and it shows that quality of work life is a positive predictor of organizational commitment. Thus, organizational commitment of teacher mostly depends upon his quality of work life. Among dimensions of quality of work life, Safe and healthy working, growth opportunity, constitutionalism in organization, social dependency, social integration, immediate opportunity to develop Human progress capabilities had significant relationship with three dimensions of organizational commitment (affective, continuance and normative commitments) and Adequate and fair compensation and total life space had significant association with affective and normative commitment. The findings of this study are consistent with a part of the results of study of Mahdad, Mahdavirad and Golparvar (2011) as there is a significant relationship between growth opportunity and security and human progress capabilities with three dimensions of organizational commitment as affective, continuance and normative and between Safe and healthy working and Adequate and fair compensation with affective and normative commitment and between constitutionalism in organization and social integrity with continuance and normative commitment. Also, the results are inconsistent with the other findings regarding the lack of relationship between constitutionalism in organization and social dependence with affective commitment and no relation between Safe and healthy working with continuance commitment. As it was said, if quality of work life ofhealth care professionalsis increased, their organizational commitment is increased. The high consideration to work place of health care professionals, creating growth opportunities, constitutionalism of organization, social dependence, social integrity and immediate develop for human progress capabilities can increase the interest ofhealth care professionalsto organization to stay and increase their normative commitment. Also, Adequate and fair compensation and considering the life conditions of health care professionals can improve their attachment to organization and their obligation to continue working with organization. The quality of work life as a culture creates high level of mutual commitment between people and organization. It means that people are committed to organization goals and its development and the organization can be committed to the needs of people and their development. Thus, the organization considering the quality of work life of employees has committed labor force and high commitment of labor force means high productivity of labor force (Organ, 1988). Strong relationship between quality of work life dimensions and total quality of work life with different organization commitment types show the strong relation between the mentioned variables and the relationship is positive. The existing solutions can be used to increase organizational commitment to improve quality of work life and based on two way relationship, the quality of work life programs are effective factors on increasing commitment of employees. one of the solutions is increasing affective consistency in employees and their involvement with organization goals, improvement of social relation networks at work, participation of employees in decision making, evaluation of performance of employees to create work feedback, explanation of goals and organizational missions, elimination of work barriers, emphasis on aspects leading to the social value of organization, creating suitable punishment and rewarding systems, elimination of bias and unsuitable relations of people at work place, relative autonomy for duties, good ground to create creativity and innovation of employees (Ranjbarian, 1996), job enrichment, giving facilities, delegating high level of responsibility to people for job (Stron, 1998).

It can be said that if Health care professionals are satisfied with their benefits, they have safe and healthy work place, opportunity for job growth, job security, constitutionalism in organization, they consider unity and integration in organization and job as revealing their individual capabilities, feel trust among the coworkers and consider their job consistent with life conditions, their organizational commitment is increased and they continue work with much interest and good results can be given to education and society. As the quality of work life of employees can be affected by their organizational commitment, if education organization attempts to increase commitment and attachment of health care professionals, it should consider their quality of work life and provide mechanisms for its promotion.

\section{Recommendations}

1. Conducting researches on effective factors on quality of work life and organizational commitment of employees.

2. The investigation of the attitude of Health care professionalshealth care professionalsabout effective factors on quality of work life and organizational commitment.

3. The investigation of the relationship between dimensions of quality of work life with organizational commitment dimensions in other levels in Health care sector among Physicians and Nurses.

4. The investigation of the opinion of managers and experts of education to quality of work life and quality of 
work life among Health care professionals.

5. The investigation of operating solutions of increasing quality of work life and organizational commitment in Health care professionals.

\section{References}

[1] AliReza Bakhshayesh1, Mehdi Rahimi2, Hojat Eftekhari Yazd, Iran. A survey of the effect of dimensions of quality of work life on organizational commitment dimensions. Scro research annual report vol. 3, pp. 1-9, 2015 issn 1494-7617.

[2] Ahsan, N., Abdullah, Z., Fie, D. G., \& Alam, S. S. (2009). A study of job stress on job satisfaction among university staff in Malaysia: Empirical study. European journal of social sciences, 8(1), 121-131.

[3] Albrecht, K. (2013). Employee Quality of Work Life Survey (EQWLS). Karl Albrecht International.

[4] Allen, N. J., \& Meyer, J. P. (1990). The measurement and antecedents of affective, continuance and normative commitment to the organization. Journal of occupational psychology, 63(1), 1-18.

[5] Altbach, P. G., Reisberg, L., \& Rumbley, L. E. (2009). Trends in global higher education: Tracking an academic revolution.

[6] Arif, S., \& Ilyas, M. (2013). Quality of work-life model forhealth care professionalsof private universities in Pakistan. Quality Assurance in Education, 21(3), 282-298.

[7] Arokiasamy, L., Ismail, M., Ahmad, A., \& Othman, J. (2009). Background of Malaysian Private Institutions of Higher Learning and Challenges Faced By Academics. Journal of International Social Research, 2(8).

[8] Arora, V., \& Kamalanabhan, T. J. (2010). Linking Supervisor and Coworker Support to Employee Innovative Behavior at Work: Role of Psychological Conditions.

[9] Bashir, S., \& Ramay, M. I. (2008). Determinants of Organizational Commitment A Study of Information Technology Professionals in Pakistan. Journal of Behavioral \& AppliedManagement, $9(2)$.

[10] Bernard, B. (2012). Factors that determine academic staff retention and commitment in private tertiary institutions in Botswana: Empirical review. Global Advanced Research

[11] Journal of Management and Business Studies (ISSN: 2315-5086), 1(9), 278-299.

[12] Bhate, R. (2013). Supervisor supportiveness: Global Perspectives. the Sloan Center on Aging \&Work at Boston College.

[13] Bindu, J., \& Yashika, S. (2014). Quality of Work Life with Special Reference to Academic Sector. Research Journal of Management Sciences, 3(1), 14-17.

[14] Boas, A. A. V., \& Morin (2013), E. M. Quality of Working Life in Public Higher Education Institutions: the perception of Brazilian and Canadian professors.

[15] Boshoff, C., \& Mels, G. (1995). A causal model to evaluate the relationships among supervision, role stress, organizational commitment and internal service quality. European Journal of marketing, 29(2), 23-42.

[16] Casper, W. J., Harris, C., Taylor-Bianco, A., \& Wayne, J. H. (2011). Work-family conflict, perceived supervisor support and organizational commitment among Brazilian professionals. Journal of Vocational Behavior, 79(3), 640-652.

[17] Chao, K. L. (2010). Relationship among Organizational Commitment, Job Characteristics, Job Satisfaction, and Turnover Intention within Kindergartens: An Empirical Study in Malaysia. 179-204. Chin, C. (2014, May 18) Exodus of Medical Lecturers. The Sunday Star, pp. 8

[18] Cohen \& Willis (1985) and Viswesvaran et al., (1999) as cited by Casper, W. J., Harris, C., Taylor-Bianco, A., \& Wayne, J. H. (2011). Work-family conflict, perceived supervisor support and organizational commitment among Brazilian professionals. Journal of Vocational Behavior, 79(3), 640-652.

[19] Daud, N. (2010). Investigating the Relationship between Quality of Work Life and Organizational Commitment amongst Employees in Malaysian Firms. International Journal of Business \& Management, 5(10).

[20] Daud, N. (2010). Quality of work life and organizational commitment amongst academic staff: Empirical evidence from Malaysia. 2010 International Conference on Education, Management and Technology (ICEMT), (pp. 271-275).

[21] Dawley, D. D., Andrews, M. C., \& Bucklew, N. S. (2008). Mentoring, supervisor support, and perceived organizational support: what matters most? Leadership \& Organization Development Journal, 29(3), 235-247.

[22] Easton, S., \& Van Laar, D. (2013). QoWL (Quality of Working Life): what, how, and why?. Psychology Research, 3(10), 596-605.

[23] Eisenberger, R., Stinglhamber, F., Vandenberghe, C., Sucharski, I. L., \& Rhoades, L. (2002).

[24] Perceived supervisor support: contributions to perceived organizational support and employee retention. Journal of applied psychology, 87(3), 565.

[25] Farjad, H. R., \& Varnous, S. (2013). Study of Relationship of Quality of Work Life (QWL) and Organizational Commitment. Interdisciplinary Journal of Contemporary Research in Business, 4 (9), 449-456.

[26] Fatima, N., \& Sahibzada, S. A. (2012). An empirical analysis of factors affecting work life balance among university health care professionals: the case of Pakistan. Journal of International Academic Research, 12(01).

[27] Hammer, Kossek, Yragui, Bodner, \& Hanson (2009) as cited by Kopp, L. (2013). The Effects of Perceived Supervisor Work-Life Support on Employee Work-Life Balance, Job Satisfaction, Organizational Commitment, and Organizational Citizenship Behavior.

[28] Hyde, A.M., Gill, M., Agrawal, K., Gupta, B., \& Sethi, M. (2012). A Study of Quality of Work Life and Organizational Commitment amongst Academician. Pacific Business Review International, 4(4), 131-144.

[29] Idris, M. K. (2011). Over time effects of role stress on psychological strain among Malaysian public university academics. International Journal of Business and Social Science, 2(9), 154-61.

[30] Kopp, L. (2013). The Effects of Perceived Supervisor Work-Life Support on Employee Work-Life Balance, Job Satisfaction, Organizational Commitment, and Organizational Citizenship Behavior.

[31] Lew, T. Y. (2009). The relationships between perceived organizational support, felt obligation, affective organizational commitment and turnover intention of academics working with private higher educational institutions in Malaysia. European Journal of Social Sciences, 9(1), 72-87.

[32] Mallika, N., \& Ramesh, D. M. (2010). Job Satisfaction in Banking: A Study of Private and Public Sector Banks. International Journal of Management (IJM), 1(1), 111-129.

[33] Meyer, J. P., \& Allen, N. J. (1991). A three-component conceptualization of organizational commitment. Human resource management review, 1(1), 61-89.

[34] Norizan, I. (2012). Organizational Commitment and Job Satisfaction Among Staff of Higher Learning Education Institutions in Kelantan (Doctoral dissertation, Universiti Utara Malaysia).

[35] Normal, MJ, Md Nor, Ishak. I (2015) Influence of Normative Beliefs on Behavioral Intention of Malaysian Digital Gamers to Continue Playing Digital Games. International Journal of Computer System, Vol 2, Issue 3. http://www.ijcsonline.com/.

[36] Obi, H., Chiamaka, J.A, \& Tochukwu, O., (2013). Job Characteristics as Predictors of Organizational Commitment Among Private 
Sector Workers in Anambra State, Nigeria. International Journal of Asian Social Science, 3(2), 482-491.

[37] Onn, C. Y., Peng, T. L., \& Lung, C. K. (2014). Supervisory Support, Organizational Justice and Perceived Organizational Support: A Review and Research Agenda. Information Management \& Business Review, 6(5).

[38] Pallant, J.F. (2005). SPSS Survival Manual - A Step By Step Guide to Data Analysis Using SPSS for Windows (Version 12). Allen \& Unwin.

[39] Parvar, M.R.F, Allameh, S. M., \& Ansari, R. (2013). Effect of quality of work life on organizational commitment by SEM (case study: OICO company). International Journal of Academic Research in Business and Social Sciences, 3(10), 135-144.

[40] Permarupan, P.Y., Al-Mamun, A., \& Saufi, R.A. (2013). Quality of Work Life on Employees Job Involvement and Affective Commitment between the Public and Private Sector in Malaysia. Asian Social Science, 9(7), 268-278.

[41] Rao, B. P. \& Gebremichael, H.,(2013). Job satisfaction and organizational commitment between academic staff and supporting staff (Volaita Sodo University-Ethiopia as a case). Far East Journal of Psychology and Business, 11(2), 11-32.

[42] Saad, H. A., Samah, A. J. A., \& Juhdi, N. (2008). Employees' perception on quality work life and job satisfaction in a private higher learning institution. International Review of Business Research Papers, 4(3), 23-34.

[43] Sáez- Bayona, C., Goñi-Legaz, S., \& Madorrán-García, C. (2009). How to raise commitment in public university lecturers. International Review of Administrative Sciences, 75(2), 333-347.

[44] Sajjad, N. K., \& Abbasi, B. (2014). Studying the Relationship between Quality of work life and Organizational Commitment. Research Journal of Recent Sciences, 3(2, 92-99.

[45] Sekaran, U., \& Bougie, R. (2010). Research Methods for Business - A Skill Building Approach. John \& Wiley Sons, Ltd, $5^{\text {th }}$ Edition. Soulen, S. K. (2003). Organizational Commitment, Perceived Supervisor Support, and Performance: A Field Study.

[46] Ünüvar, T. G. (2006). An integrative model of job characteristics, job satisfaction, organizational commitment, and organizational citizenship behavior (Doctoral dissertation, Middle East Technical University).

[47] Watt. S. (2011). Good Practice in the Supervision \& Mentoring of Postgraduate Students - It Takes an Academy to Raise a Scholar. McMaster University.

[48] Wilkins, K., \& Beaudet, M. P. (1998). Work stress and health. Health Reports, 10(3), 47-62.

[49] Winter, R., Taylor, T., \& Sarros, J. (2000). Trouble at mill: Quality of Academic Worklife Issues within a Comprehensive Australian University. Studies in Higher Education, 25(3), 279-294.

[50] Zakaria, Z. B., Ahmad, A. B., \& Norzaidi, M. D. (2009). Determining World Class University from the Evaluation of Service Quality and Students Satisfaction Level: An Empirical Study in Malaysia. International Journal of Scientific Research in Education, 2(2), 59-66. 